\title{
Saint Jerome as a Model and Author for Nuns in Early Hungarian Texts
}

\section{Ágnes Korondi*}

In the third decade of the sixteenth century, the nuns residing in the wealthy and prestigious Dominican cloister on the Island of Hares (today's Margaret Island, Budapest) were on the point of abandoning their monastery due to the Ottoman occupation of Central Hungary. In these years, one of the nuns, Márta Sövényházi, compiled a voluminous miscellaneous manuscript in Hungarian ${ }^{1}$ for the use of her convent. Apart from planning the structure of the codex, which was meant to serve as a "portable library," easy to carry if and when the community had to flee, ${ }^{2}$ Sister Márta also copied two-thirds of the manuscript and was thus its main scribe. As Lea Haader, who analyzed her scribal activity, observed, the sister was a careful scribe. She hardly ever left out letters or words and emended both her and her fellow scribes' work. ${ }^{3}$ One of Sövényházi's copying mistakes, which she noticed and corrected immediately, was substituting the name Jerome for that of Jeremiah in the last line of the first column on folio 83r. According to Haader, this slip of the pen falls into the category of stereotypical word exchange, which occurred when the

* Res Libraria Hungariae Research Group, Hungarian Academy of Sciences National Széchényi Library, Budapest; korondi.agnes@oszk.hu. The paper was prepared within the HAS-NSzL Res Libraria Hungariae Research Group.

1 Érsekújvári Codex, Library and Information Centre of the Hungarian Academy of Sciences, Department of Manuscripts and Rare Books, Budapest (hereafter: LICHAs), K 45. Edition by Lea Haader, Érsekújvári Kódex, Régi magyar kódexek 32 .

2 Madas, “Az Érsekújvári Kódex mint a menekülő apácák hordozható könyvtára és két új forrásazonosítás (Műhelytanulmány)," 91-104.

3 Haader, "Arcképtöredékek ómagyar scriptorokról," 72-74, "Írásbeli megakadásjelenségek történeti pszicholingvisztikai szemszögből,” 48-65. 
scribe automatically wrote down a well-known and frequently used formula or a stereotypical expression instead of an infrequent one. ${ }^{4}$ Because otherwise the sister committed such errors less frequently than male scribes, ${ }^{5}$ the substitution of Jerome's name for Jeremiah's is even more revealing. It indicates that the name of the Church Father came more easily to the Dominican nun than that of the prophet when seeing the name of an authority beginning with the letters Jer-. How popular was, in fact, Saint Jerome in the vernacular literature of late medieval Hungary? Was he indeed a well-known figure among literate nuns? Furthermore, in what capacity was he popular among the writers and readers of Hungarian-language literature? The paper will attempt to answer these questions.

Jerome was venerated during the late Middle Ages in the Hungarian Kingdom, even though the great biblical philologist was far from being among the most popular saints of the country. According to the testimony of textual and visual sources, such as sermons, church wall paintings, or altarpieces, ${ }^{6}$ he was in general honored as one of the four Latin Fathers and often represented in the company of Ambrose, Augustine, and Gregory the Great. By the end of the Middle Ages, however, the increasing number of sources and an upsurge in his cult ${ }^{7}$ enables us to analyze Jerome's reception by different smaller Hungarian communities, who interpreted his figure slightly differently, emphasizing this or that aspect of his long life and varied theological and philological activity. The community best known by contemporary international scholarship was formed by the humanists of King Matthias' court, who appreciated the saint's philological and historical achievements as well as his style. ${ }^{8}$ The community whose

4 Haader, "Írásbeli megakadásjelenségek," 56.

5 Ibid., 56.

6 The churches and monasteries dedicated to him are listed in Mezö, Patrocíniumok a középkori Magyarországon, 160-61. The most important textual and visual sources of Jerome's Hungarian cult are mentioned by Bálint, Ünnepi kalendárium: A Mária-ünnepek és jelesebb napok hazai és közép-európai hagyományvilágából, vol. 2, 335-36. For the representations of Jerome on altarpieces in medieval Hungary see Radocsay, A középkori Magyarország táblaképei, 260, $285,373,436,441,453$.

7 On the reshaping and development of his cult in this period, see Rice, Saint Jerome in the Renaissance.

8 They owned several high-quality manuscripts containing Jerome's works, see Csapodi and Csapodiné Gárdonyi, Bibliotheca Hungarica: Kódexek és nyomtatott könyvek Magyarországon 1526 elött, vol. 1-3. The famous Corvina Library contained seven codices with works by Jerome. For further detail see: "Virtual 
image of Jerome is discussed here is a much less lettered group, consisting mainly of moderately educated nuns, tertiaries, and lay brothers, as well as some wealthy laypersons connected with specific monastic communities as patrons. They are, in short, the readership of the first significant body of Hungarian-language texts.

This corpus of approximately 45 surviving codices ${ }^{9}$ was created in the last decades of the 15 th and first four decades of the 16 th century. ${ }^{10}$ Most of them were copied for and by the Dominican nuns living on the Island of Hares and the Poor Clares of Old Buda. Both these cloisters were founded by the royal family and were exceptionally wealthy. The nuns usually were of noble, occasionally even of royal birth $;{ }^{11}$ therefore, their level of education was presumably higher than that of an average late medieval Hungarian nun. Moreover, both monasteries were influenced by the Observant reform movement, which regarded vernacular literature as a useful educational and devotional tool. The Hungarian-language manuscripts were meant to serve as communal and private readings for the sisters whose mastery of the Latin language probably did not rise above the ability to recite and to understand, to some degree, the texts of the Holy Office. Therefore, the manuscripts prepared for them contained the Hungarian translation of religious rules, sermons, legends, exempla, prayers, biblical and liturgical texts, as well as various treatises and teachings about religious life, virtues and vices, death, and the afterlife. Some other similar manuscripts were

Corvinas," Bibliotheca Corvina Virtualis, National Széchényi Library, available online. Out of these two were displayed in the Corvina exhibition organized in 2018-2019 in the National Széchényi Library, Budapest. For their short English and detailed Hungarian descriptions, see Zsupán and Földesi, The Corvina Library and the Buda Workshop: A Guide to the Exhibition, 92, 150; Pócs, "D12 (= Kalauz / Guide 2018, Kat. D12) Szent Jeromos: Kommentár Szent Pál leveleihez (Commentarii in Epistolas S. Pauli ad Galatas, ad Ephesios, ad Titum, ad Philemonem): Nicolaus de Lyra: Postilla a zsidókhoz írt levélhez (Postilla super S. Pauli Epistolam ad Hebraeos)," 231-34; Zsupán, "F 8 (= Kalauz / Guide 2018, Kat. F8) Eusebius Krónikájának második könyve (Chronikoi kanones) Szent Jeromos latin fordításában,” 309-11.

9 The exact number is debatable, because some of these manuscripts are only fragments called codices in the Hungarian secondary literature. Some were divided into several parts during the nineteenth century, while others consist of several parts that were probably bound together later than the Middle Ages.

10 Horváth, A magyar irodalmi müveltség kezdetei: Szent Istvántól Mohácsig, 111290.

11 Romhányi, "The Monastic Topography of Medieval Buda," 210-11, 221-22, Klaniczay, "Sacred Sites in Medieval Buda," 229-54. 
prepared for Franciscan tertiary communities and Premonstratensian nuns. ${ }^{12}$ The Pauline hermits of Nagyvázsony and the Carthusians of Lövöld also compiled books in the vernacular for their wealthy lay patrons and the lay brothers and sisters of their order.

Jerome is a prominent figure in these Hungarian-language manuscripts. Some of the codices contain texts attributed to him; others include legends and exempla about his life and miracles. Two Bible translators mention him as a model. In addition, the vernacular sermon collections often quote him as an authority, although the general practice in transposing scholastic sermons was to omit some of the references or substitute phrases such as "the doctors state" for the name of the cited author. The translators and scribes did not wish to burden their readers with potentially unfamiliar names. ${ }^{13}$ Jerome's name was often included, demonstrating that he was considered a well-known author even among nuns, tertiaries, and laypersons not very well-versed in patristic literature. In what follows, I will discuss the Hungarian-language texts attributed to or speaking about Saint Jerome and provide a short overview of the codices that contain them. Finally, I will underline why the given text could have been considered helpful for the intended audience, and what aspects of Jerome's life and activity were emphasized as worthy of admiration and imitation.

Among the works attributed to Jerome in the Hungarian corpus, only one goes back partly to a text authored indeed by him: the life of Saint Paul, the First Hermit, preserved in a manuscript of legends and prayers. ${ }^{14}$ It was copied in the early sixteenth century by the Pauline Hermits for a layperson named Simon, probably a patron of the monastery of Nagyvázsony. ${ }^{15}$ This order of hermits of Hungarian origin, named after Paul of Thebes, whose relics were then preserved in the monastery of Budaszentlörinc, valued Paul's legend and Jerome as its author and a major champion of ascetic life. Therefore, it was natural for them to propagate this text even in Hungarian among those connected with their order. The Hungarian text was not a

On the manuscript culture of these female religious communities see Lázs, Apácamüveltség Magyarországon a XV-XVI. század fordulóján: Az anyanyelvü irodalom kezdetei.

About the handling of authorities in the Hungarian vernacular see Tarnai, " $A$ magyar nyelvet írni kezdik": Irodalmi gondolkodás a középkori Magyarországon, 263.

4 Peer Codex, National Széchényi Library, Manuscript Collection, Budapest (hereafter NSZL), MNy 12, 18v-58r. Edition by Kacskovics-Reményi and Oszkó, Peer-kódex, Régi magyar kódexek 25.

5 Kacskovics-Reményi and Oszkó, "Bevezetés," 15-16. 
word-for-word translation of Jerome's Vita Pauli. However, parts of it originated directly from Jerome's text. The translator referred to the original author several times in phrases such as "Saint Paul the first hermit, as Saint Jerome who wrote his life testifies." ${ }^{{ }^{16}}$ The compiler and translator of the vernacular text may have used the 1511 Venice edition of the legend published by the erudite Pauline Father, Bálint Hadnagy. ${ }^{17}$

The ascetic life is also the topic of a religious rule attributed to Jerome during the Middle Ages, copied for the Dominican nuns on the Island of Hares into the same manuscript as the legend of Saint Francis of Assisi. ${ }^{18}$ The translation of the Regula monachorum is not complete. The text ends mid-sentence abruptly. While the original rule has forty-one chapters, there are only twenty-one in the Virginia Codex. Several chapters have been abbreviated; some have been merged or left out. ${ }^{19}$ The text was adapted to the needs of Dominican nuns, teaching them about the fundamental virtues required by communal life (such as humility, obedience, and unity), the rights and duties of the prioress, or the correct behavior in the company of laypersons, and several other aspects of religious life. Since the rule was allegedly addressed to Eustochium, Jerome's spiritual daughter, and her community of women, the Church Father was represented as the teacher of women and a founder and patron of female communities.

The Latin original of the Pseudo-Jerome sermon copied into the

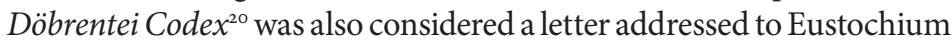
(and her mother, Paula). The compiler of this manuscript, Bertalan, a priest from the village of Halábor, selected primarily texts related to the liturgy: a complete psalter with canticles and some hymns, biblical pericopes for the entire year, and breviary readings. The alleged Hieronymian letter, ${ }^{21}$ in fact written by Paschasius Radbertus, ${ }^{22}$ was a

E.g., Peer Codex, fol. 18v.

Gábor, "Kitalált szent, valós kultusz (Remete Szent Pál)? Szövegek tanúságai," 77-81.

Virginia Codex, LICHA, K 40, fol. 77r-91v. Edition by Kovács, Virginia-kódex, Régi magyar kódexek 11.

Timár, "Adalékok kódexeink forrásaihoz," 264-67.

Döbrentei Codex, Alba Iulia, Batthyaneum Library, Romanian, Ms in 76, fol. 248r-255v. Edition by Abaffy and T. Szabó, Döbrentei-kódex, Régi magyar kódexek 19.

[Pseudo]-Hieronymus, Epistola 9: Ad Paulam et Eustochium de assumptione beatae Mariae Virginis, PL 30, 126-147 / 122-142. BHL 5355d. CPL 633.

, Der Pseudo-Hieronymus-Brief IX 'Cogitis me': Ein Erster Marianisch Traktat des Mittelalters von Paschasius Radbert. "Paschasii Radberti Epistula 
breviary reading, being therefore well-known in the age. No wonder its passages (attributed, of course, to Jerome) occur eighteen times in various Hungarian-language sermon collections, ${ }^{23}$ the most favored quotation being the one that compares the virgin state to angelic life. ${ }^{24}$ This and several other citations attributed to Jerome figured in the frequently used florilegia, summae, and model sermon collections used by the preachers of the age. ${ }^{25}$ For example, the quote on angelic life appears at the headword virginitas in the Tabula alphabetica of the popular sermon collection entitled Pomerium Sermonum. ${ }^{26}$ This volume, written by the Hungarian Observant Franciscan, Pelbartus of Temesvár, and his Mariological compendium, the Stellarium coronae beatae virginis Mariae ${ }^{27}$ were the direct Latin sources of most Hungarian-language quotes from Jerome..$^{28}$ The references show that the readers of these vernacular texts got to know Jerome as an authority on ascetic life, virginity, Mariology, and biblical philology.

It is Jerome, the biblical philologist, to whom two Hungarian Bible translators referred when naming him as a model in their works. A Transylvanian Franciscan, András Nyújtódi, compiled the colophon to his own Hungarian translation of the Book of Judith ${ }^{29}$ by borrowing passages from Jerome's preface to this biblical book. Since Nyújtódi prepared the text for his sister Judith, a Franciscan tertiary, so that she would not be in her cell without the book of her saint, ${ }^{30}$ the Hungarian Friar could easily emulate Jerome's role as a teacher and spiritual guide for nuns. Moreover, in true Hieronymian fashion, he added short historical and cultural explanations to the

Hieronymi ad Paulam et Eustochium de Assumptione Sanctae Mariae Virginis," 97-162.

Korondi, "Szent Jeromos, az auctor a késő középkori magyar nyelvű kódexekben."

"[Q]uia semper angelis cognata virginitas. Profecto in carne, praeter carnem vivere, non terrena vita est, sed coelestis." PL 30, 130-131 / 126-127.

On such collections see Bárczi, Ars compilandi: A késő középkori prédikációs segédkönyvek forráshasználata: A hiteles információk összegyüjtésének kevéssé bevallott módszerei: Az intertextualitás információs rendszerei, 108-27. Pelbartus de Themeswar, Pomerium de sanctis, fol. 2viiir.

27 [Pelbartus de Themeswar], Stellarium coronae beatae virginis Mariae.

28 Korondi, "Szent Jeromos, az auctor."

29 Székelyudvarhelyi Codex, Odorheiu Secuiesc, Romania, Haáz Rezső Múzeum Tudományos Könyvtár, fol. 1r-52r. Edition by N. Abaffy, Székelyudvarhelyi Kódex, Régi magyar kódexek 15. 
more difficult passages to help his probably not-that-thoroughly-educated sister understand the book better.

Another self-proclaimed follower of Jerome's translating activity also considered the needs of his cloistered sister and other nuns and lay brothers belonging to various orders. The monk known only as the Carthusian Anonym translated and compiled a voluminous book of pericopes and sermons ${ }^{31}$ to offer spiritual food to the brothers and sisters who could not read such texts in Latin. He also intended his work as a weapon to be used against the "pestilential Lutheran heresy" spreading all over Europe..$^{32} \mathrm{~A}$ Latin prologue introduces the codex, which literary historians regard as the first Hungarian literary program ${ }^{33}$ Here, the Anonym draws attention to the shameful lack of Hungarian Bible translations. Comparing his people to other nations in this respect, he refers to Jerome:

I have been wondering in holy meditation how most people speaking different languages have complete translations of the Bible in their mother tongues - let us only consider the German, Czech, French, or, here in our neighborhood, the Slavic language. To this, the divine Jerome transposed with remarkable skill not only the Bible itself but also the entire liturgy based on Hebrew, Greek, and Latin texts with new letters, and the same may be seen in others. Yet our uncouth and uneducated Hungarian people has not been permeated by grace to be able to boast of such merits even in the form of drafts. I believe that this must be attributed to laziness and negligence rather than to ignorance. ${ }^{34}$

Érdy Codex, NSzL, mny 9. Edition by György Volf, Érdy codex, 2 vols., Nyelvemléktár, 4-5.

“[P]estifera luteriana heresi [...]” Érdy Codex, fol. 1rb.

Tarnai, "A magyar nyelvet írni kezdik," 281-84.

34

"Hoc igitur sacracius mente tractans, vt qm omnium linguarum Naciones in sua lingua materna fere totam Bibliam habent translatam puta Theutonica, Bohemica francigena Gallica. Sic prope nos et Slaonica In quam Diuinus Ieronimus Non modo bybliam ipsam, sed et nouis literis ad instar hebraicarum, grecarum et latinarum totum officium sacerdotale miro ac modo subtilissimo conuertit: Sic et de ceteris est videre. hec autem nostra gens hungara tam rudis et rustica minime tali irroratur gracia vt more conmentariorum huiusmodi dignum ferre posset Quod non vicio ignorancie quinpocius ocy et negligencie ascribendum fore puto." Érdy Codex, fol. 1ra. Volf, Érdy codex, vol. 1, xxiii. 
The popular misbelief that Jerome prepared a Slavic translation of the Bible and the liturgy, as well as having invented the Glagolitic alphabet, was discussed in detail by Julia Verkholantsev..$^{35}$ While the legend could have reached Hungary from the direction of Bohemia with a possible Polish mediation, the Carthusian Anonym must have come by it via Hungary's Croatian or Dalmatian neighbors ${ }^{36}$ since he probably lived in the southern Hungarian monastery of Lövöld. For the would-be Hungarian Bible translator, the Slavic apostle was not only a model to imitate but also an illustrious representative of a neighboring culture with whom he wished to contend.

Apart from referring to Jerome as a model translator, the codex of the Carthusian Anonym also spoke about the saint's life. The manuscript contains a sermon for the saint's feast, which also encompasses his legend. ${ }^{37}$ The sermon emphasizes Jerome's true wisdom, contrasting it to self-serving, vain knowledge. The Hungarian famulus of the holy scholar often resorted to this wisdom: there are fifty-seven references to Jerome in the Érdy Codex, ${ }^{38}$ which is a record within the discussed corpus (the second-highest number of quotations is twenty-four). The most significant part of the codex's legend is based on the Legenda aurea. ${ }^{39}$ However, the Carthusian Anonym also used another hagiographical source, which was crucially important in the evolution of Jerome's cult. ${ }^{40}$ The three apocryphal letters attributed to St. Augustine, Eusebius of Cremona, and Cyril of Jerusalem describe Jerome's death and the post-mortem miracles. The three texts, also known as Vita et transitus Sancti Hieronymi, were popular on both coasts of the Adriatic Sea in the fifteenth and the early sixteenth centuries. ${ }^{41}$ Since I have discussed the possible routes by which the three letters arrived

Verkholantsev, The Slavic Letters of St. Jerome: The History of the Legend and Its Legacy, or, How the Translator of the Vulgate Became an Apostle of the Slavs.

On Jerome's cult in Dalmatia, see Ivić, "Jerome Comes Home: The Cult of Saint Jerome in Late Medieval Dalmatia," 618-44, "The 'Making' of a National Saint: Reflections on the Formation of the Cult of Saint Jerome in the Eastern Adriatic," 247-78. Érdy Codex, fol. 28ov-283v. Volf, Érdy codex, vol. 2, 560-66.

38 Imre Bán counted fifty-four mentions in his book A Karthausi Névtelen müveltsége, 50-51. Horváth, Középkori legendáink és a Legenda aurea, 39-40.

40 Rice, Saint Jerome, 49-63.

41 Ivić, "The Cult of Saint Jerome in Dalmatia in the Fifteenth and the Sixteenth Centuries," 40-42, "Circulation of Vita et Transitus Sancti Hieronymi along the Eastern Adriatic Coast in the Late Middle Ages," 125-139. 
to Hungary in detail elsewhere, I will not elaborate on it here. ${ }^{42}$ Suffice it to say, they also penetrated the burgeoning Hungarian-language literature of the early sixteenth century.

Apart from three short references to the episode of the three men resurrected beside Jerome's grave from the letter by Pseudo-Cyril, the bulky codex of Márta Sövényházi, mentioned at the beginning of this paper, contains the translation ${ }^{43}$ of Pseudo-Augustine's Epistola ad Cyrillum de magnificentiis beati Hieronymi. ${ }^{44}$ With the transposition of this letter, the translator somewhat overreached himself, as the vernacular text is rather difficult to understand. Fortunately for the intended readers, the codex contains the life of Jerome from the Golden Legend as well. ${ }^{45}$ This made it easier to appreciate Jerome's greatness even for those who got lost in the complicated sentences of Pseudo-Augustine.

The translator of a miracle narrative, ${ }^{46}$ originating from the letter by Pseudo-Cyril, ${ }^{47}$ had a much easier task than the interpreter of PseudoAugustine since the exemplum is a colorful story, illustrating how useful it is for a nun to keep an image of Jerome in her cell. The Franciscan Friar, Ferenc Lippai, who compiled the Kazinczy Codex, seems to have preferred such tales, as he included several adventurous legends and exempla in the manuscript he prepared for the Poor Claires of Old Buda. He also copied another manuscript for this community, a codex that consists mainly of Marian sermons originating from Pelbartus of Temesvár. ${ }^{48}$ One of the exempla demonstrating the bodily taking up of the Virgin into Heaven also includes Jerome as a character. ${ }^{49} \mathrm{~A}$

42 Korondi, "A Vita et transitus Sancti Hieronymi keletközép-európai és magyarországi elterjedéséről," 193-211.

43 Érsekújvári Codex, fol. 165v-171r.

44 [Pseudo]-Augustinus, Epistola Augustini Hipponensis episcopi ad Cyrillum Jerosolymitanum episcopum, de magnificentiis beati Hieronymi, PL 22, 281-289. BHL 3867. CPL 367.

45 Érsekújvári Codex, fol. 156r-158v.

46 Kazinczy Codex, NszL, mny 11, 18r-19v. Edition by Kovács, Kazinczy-kódex, Régi magyar kódexek 28.

47 [Pseudo-]Cyrillus, Epistola Cyrilli episcopi Jerosolymitani de miraculis Hieronymi ad Sanctum Augustinum episc. Hipponensem, PL 22, 289-326. BHL 3868. CPL 367. The source of the exemplum is in Chapter 13: PL 22, 309-11.

48 Tihanyi Codex, NszL, mny 75. The scribe and compiler of this manuscript was identified as Ferenc Lippai in the edition of the codex. Kovács, "Bevezetés," in Tihanyi Kódex, 20-29.

49 Tihanyi Codex, 184v-85r. Its source: [Pelbartus de Themeswar]: Stellarium, Lib. $\mathrm{X}$, pars I, art. III. 
friar refuses to honor his feast because, in the abovementioned sermon on the Assumption (which in fact was authored by Paschasius Radbertus), the saint did not clarify the issue of the bodily assumption. Mary and Jerome have to appear before him in a vision and explain this lapse. The story is additionally included in a Dominican collection of Marian sermons, which was also translated from Pelbartus' Stellarium..$^{50}$

All these texts by and about Jerome suggest that the saint was well known and honored among the compilers and readers of the late medieval Hungarian-language literature. He was appreciated as a great Marian theologian and biblical philologist whose austere and saintly life made him an authority in asceticism and monastic life at the same time. The slip of pen committed by Márta Sövényházi and mentioned in the introductory paragraph of this paper is a small but quite suggestive testimony to the popularity of the Church Father in the first decades of the sixteenth century, even among mainly Hungarian-speaking nuns. 


\section{BIBLIOGRAPHY}

Abaffy, Csilla, and Csilla T. Szabó, eds. Döbrentei-kódex, 1508: Halábori Bertalan keze írásával: A nyelvemlék hasonmása és betühü átirata bevezetéssel és jegyzetekkel [Döbrentei Codex, 1508: Written by the hand of Bertalan Halábori: The facsimile and transliteration of the early Hungarian text with an introduction and notes]. Régi Magyar Kódexek 19. Budapest: Argumentum Kiadó and Magyar Nyelvtudományi Társaság, 1995.

—_, ed. Székelyudvarhelyi Kódex, 1526-1528: A nyelvemlék hasonmása és betühü átirata bevezetéssel és jegyzetekkel [Székelyudvarhelyi Codex, 1526-1528: The facsimile and transliteration of the early Hungarian text with an introduction and notes]. Régi magyar kódexek 15. Budapest: Magyar Nyelvtudományi Társaság, 1993.

Augustinus, [Pseudo-]. Epistola Augustini Hipponensis episcopi ad Cyrillum Jerosolymitanum episcopum, de magnificentiis beati Hieronymi. PL 22, 281-289.

Bálint, Sándor. Ünnepi kalendárium: A Mária-ünnepek és jelesebb napok hazai és közép-európai hagyományvilágából [Festive calendar: Marian feasts and important days from the autochthonous and European tradition], vol. 2. Budapest: Szent István Társulat, 1977.

Bán, Imre. A Karthausi Névtelen müveltsége [The erudition of the Carthusian Anonym]. Budapest: Akadémiai Kiadó, 1976.

Bárczi, Ildikó. Ars compilandi: A késő középkori prédikációs segédkönyvek forráshasználata: A hiteles információk összegyüjtésének kevéssé bevallott módszerei: Az intertextualitás információs rendszerei [Ars compilandi: The use of sources in the late medieval handbooks of sermon making: The little acknowledged methods of gathering authentic information: The informational systems of intertextuality]. Budapest, Universitas, 2007.

Csapodi, Csaba, and Klára Csapodiné Gárdonyi. Bibliotheca Hungarica: Kódexek és nyomtatott könyvek Magyarországon 1526 elött [Bibliotheca Hungarica: Codices and printed books in Hungary before 1526], vol. 1-3. Budapest: MTAK, 1988-1994.

Cyrillus, [Pseudo-]. Epistola Cyrilli episcopi Jerosolymitani de miraculis Hieronymi ad Sanctum Augustinum episc. Hipponensem. PL 22, 289-326.

Döbrentei Codex. Batthyaneum Library, Alba Iulia. Ms in 76. Érdy codex. National Széchényi Library, Manuscript Collection, Budapest. MNy 9. 
Érsekújvári Codex. Library and Information Centre of the Hungarian Academy of Sciences, Department of Manuscripts and Rare Books, Budapest. K 45.

Gábor, Csilla. "Kitalált szent, valós kultusz (Remete Szent Pál)?

Szövegek tanúságai” [Imaginary saint, real cult (Saint Paul the First Hermit)? The testimony of texts]. In Laus et polemia: Magasztalás és vetekedés közép-és kora újkori szövegtípusokban [Laus et polemia: Praise and polemics in medieval and early modern text types], 69-84. Debrecen: Debreceni Egyetemi Kiadó; Kolozsvár: Bolyai Társaság, Egyetemi Mühely Kiadó, 2015.

Haader, Lea, and Zsuzsanna Papp, eds. Horvát-kódex, 1522: A nyelvemlék hasonmása és betühü átirata bevezetéssel és jegyzetekkel [Horvát Codex, 1522: The facsimile and transliteration of the early Hungarian text with an introduction and notes]. Régi magyar kódexek 17. Budapest: [Magyar Nyelvtudományi Társaság], 1994.

_ - ed. Érsekújvári Kódex, 1529-1531: A nyelvemlék hasonmása és betühü átirata bevezetéssel és jegyzetekkel [Érsekújvári Codex, 1529-1531: The facsimile and transliteration of the early Hungarian text with an introduction and notes]. Régi magyar kódexek 32. Introduction by Edit Madas and Lea Haader. Budapest: MTA Nyelvtudományi Intézete; MTAK; Tinta, 2012.

—_ "Arcképtöredékek ómagyar scriptorokról” [Fragmentary portraits of old Hungarian scribes]. In "Látjátok feleim...": Magyar nyelvemlékek a kezdetektól a 16. század elejéig [Can you see, my brothers... Monuments of the Hungarian language from the beginnings to the early sixteenth century], edited by Edit Madas, 53-78. Budapest: OsZK, 2009.

—_ . "Írásbeli megakadásjelenségek történeti pszicholingvisztikai szemszögböl” [Disfluencies in writing in a historical-psycholinguistic perspective]. Magyar Nyelvör 133.1 (2009): 48-65.

Hieronymus, [Pseudo-]. Epistola IX. Ad Paulam et Eustochium: De assumptione beatae Mariae Virginis. PL 30, 126-147 / 122-142.

Horvát Codex. National Széchényi Library, Manuscript Collection, Budapest. MNy 7.

Horváth, Cyrill. Középkori legendáink és a Legenda aurea [Our medieval legends and the Legenda aurea]. Budapest, 1911.

Horváth, János. A magyar irodalmi müveltség kezdetei: Szent Istvántól Mohácsig [The beginnings of Hungarian literary culture: From Saint Stephen to Mohács]. Budapest: Magyar Szemle Társaság, 1944. 
Ivić, Ines. "Circulation of Vita et Transitus Sancti Hieronymi along the Eastern Adriatic Coast in the Late Middle Ages." Edinost in dialog / Unity and Dialogue 75.1 (2020): 125-139.

_. "Jerome Comes Home: The Cult of Saint Jerome in Late Medieval Dalmatia." Hungarian Historical Review 5.3 (2016): 618-644.

- "The 'Making' of a National Saint: Reflections on the Formation of the Cult of Saint Jerome in the Eastern Adriatic." In Visualizing Past in a Foreign Country: Schiavoni / Illyrian Confraternities and Colleges in Early Modern Italy in Comparative Perspective, edited by Giuseppe Capriotti, Francesca Coltrinari, and Jasenka Gudel. Supplement 7 (2018), Il Capitale Culturale: Studies on the Value of Cultural Heritage: 247-278.

-. "The Cult of Saint Jerome in Dalmatia in the Fifteenth and the Sixteenth Centuries." MA thesis, Central European University, Budapest, 2016.

Kacskovics-Reményi, Andrea and Beatrix Oszkó, eds. Peer-kódex: A nyelvemlék hasonmása és betühü átirata bevezetéssel és jegyzetekkel [Peer Codex: The facsimile and transliteration of the early Hungarian text with an introduction and notes]. Régi Magyar Kódexek 25. Budapest: Argumentum Kiadó and Magyar Nyelvtudományi Társaság, 2000.

Kazinczy Codex. National Széchényi Library, Manuscript Collection, Budapest. mny 11.

Klaniczay, Gábor. “Sacred Sites in Medieval Buda.” In Medieval Buda in Context, edited by Balázs Nagy, Martyn Rady, Katalin Szende, and András Vadas, 229-254. Leiden: Brill, 2016.

Korondi, Ágnes. "A Vita et transitus Sancti Hieronymi keletközépeurópai és magyarországi elterjedéséröl” [On the dissemination of the Vita et transitus Sancti Hieronymi in East Central Europe and Hungary]. In A könyv és olvasója: A 14-16. századi könyvkultúra interdiszciplináris megvilágitásban [The book and its reader: 14-16th-century book culture in an interdisciplinary light], edited by Laura Fábián, Borbála Lovas, Péter Haraszti Szabó, and Dorottya Uhrin, 193-211. Budapest, MTA-ELTE HECE, 2018.

. "Szent Jeromos, az auctor a késő középkori magyar nyelvű kódexekben" [Saint Jerome, the auctor in the late medieval Hungarian-language codices]. In Emlék - Emlékmü - Müemlék [Memory - Memorial - Monument], edited by Anna Boreczky and Franciska Dede. Budapest: Oszk, forthcoming. 
Kovács, Zsuzsa, ed. Kazinczy-kódex, 1526-1541: A nyelvemlék hasonmása és betühü átirata bevezetéssel és jegyzetekkel [Kazinczy Codex, 1526-1541: The facsimile and transliteration of the early Hungarian text with an introduction and notes]. Régi magyar kódexek 28. Budapest: Pharma Press; Magyar Nyelvtudományi Társaság, 2003.

ed. Tihanyi Kódex, 1530-1532: A nyelvemlék hasonmása és betühü átirata bevezetéssel és jegyzetekkel [Tihanyi Codex, 1530-1532: The facsimile and transliteration of the early Hungarian text with an introduction and notes]. Régi magyar kódexek 31. Budapest: Pharma Press; Magyar Nyelvtudományi Társaság, 2007.

—_, ed. Virginia-kódex, XVI. század eleje: A nyelvemlék hasonmása és betühü átirata bevezetéssel és jegyzetekkel [Virginia Codex, beginning of the sixteenth century: The facsimile and transliteration of the early Hungarian text with an introduction and notes]. Régi magyar kódexek 11. Budapest: Magyar Nyelvtudományi Társaság, 1990.

Lázs, Sándor. Apácamüveltség Magyarországon a XV-XVI. század fordulóján: Az anyanyelvü irodalom kezdetei [Nuns' culture in Hungary at the turn of the 15th-16th centuries: The beginnings of vernacular literature]. Budapest: Balassi, 2016.

Madas, Edit. “Az Érsekújvári Kódex mint a menekülő apácák hordozható könyvtára és két új forrásazonosítás (Műhelytanulmány)" [The Érsekújvári Codex as the portable library of fleeing nuns and two newly identified sources (Working paper)]. In Szöveg - emlék - kép [Text - memory - image], edited by László Boka and Judit P. Vásárhelyi, 91-104. Budapest: Bibliotheca Nationalis Hungariae; Gondolat, 2011.

Mező, András. Patrocíniumok a középkori Magyarországon [The patron saint of the churches in medieval Hungary]. Budapest: METEM, 2003.

National Széchényi Library. "Virtual Corvinas." Bibliotheca Corvina Virtualis, available online.

Paschasius Radbertus. "Paschasii Radberti Epistula Hieronymi ad Paulam et Eustochium de Assumptione Sanctae Mariae Virginis." In De partu virginis; De assumptione sanctae mariae virginis, eds. E. A. Matter and A. Ripberg. СССм 56c. Turnhout: Brepols, 1985, 97-162.

Peer Codex. National Széchényi Library, Manuscript Collection, Budapest. mNy 12. 
Pelbartus de Themeswar. Pomerium de sanctis, Pars aestivalis. Augsburg, 1502.

[Pelbartus de Themeswar.] Stellarium coronae beatae virginis Mariae. [Basel: Jacobus Wolff, c.1497/ 1500].

Pócs, Dániel. “D12 (= Kalauz / Guide 2018, Kat. D12) Szent Jeromos: Kommentár Szent Pál leveleihez (Commentarii in Epistolas S. Pauli ad Galatas, ad Ephesios, ad Titum, ad Philemonem), Nicolas of Lyra: Postilla a zsidókhoz írt levélhez (Postilla super S. Pauli Epistolam ad Hebraeos)" [Saint Jerome: Commentaries on Galatians, Ephesians, Titus, and Philemon, Nicolaus de Lyra: Postil on Saint Paul's Epistle to the Hebrews]. In "Az ország díszére.” A Corvina könyvtár budai mühelye: Kiállitási katalógus [The Corvina Library and the Buda workshop: Exhibition catalogue], edited by Edina Zsupán, 231-234. Budapest: Országos Széchényi Könyvtár, 2020.

Radocsay, Dénes. A középkori Magyarország táblaképei [Panel paintings of medieval Hungary]. Budapest: Akadémiai, 1955.

Rice, Eugene F. Saint Jerome in the Renaissance. Baltimore: Johns Hopkins University Press, 1985.

Ripberg, Albert. Der Pseudo-Hieronymus-Brief IX 'Cogitis me’: Ein Erster Marianischer Traktat des Mittelalters von Paschasius Radbert. Spicilegium Friburgense 9. Freiburg: Universitätsverlag, 1962.

Romhányi, Beatrix F. “The Monastic Topography of Medieval Buda.” In Medieval Buda in Context, edited by Balázs Nagy, Martyn Rady, Katalin Szende, and András Vadas, 204-228. Leiden: Brill, 2016.

Székelyudvarhelyi Codex. Odorheiu Secuiesc, Romania, Haáz Rezső Múzeum Tudományos Könyvtár.

Tarnai, Andor. „A magyar nyelvet írni kezdik”: Irodalmi gondolkodás a középkori Magyarországon ["The Hungarian language starts to be written:" Literary thinking in medieval Hungary]. Budapest: Akadémiai Kiadó, 1984.

Tihanyi Codex. National Széchényi Library, Manuscript Collection, Budapest. MNy 75.

Timár, Kálmán. "Adalékok kódexeink forrásaihoz" [Additions to the sources of our codices]. Irodalomtörténti Közlemények 36.4 (1926): 264-270.

Verkholantsev, Julia. The Slavic Letters of St. Jerome: The History of the Legend and Its Legacy, or, How the Translator of the Vulgate Became an Apostle of the Slavs. DeKalb, IL: Northern Illinois University Press, 2014. 
Virginia Codex. Library and Information Centre of the Hungarian Academy of Sciences, Department of Manuscripts and Rare Books, Budapest. K 40.

Volf, György, ed. Érdy codex. 2 vols. Nyelvemléktár, 4-5. Budapest: MTA, 1876.

Zsupán, Edina, and Ferenc Földesi. The Corvina Library and the Buda Workshop: A Guide to the Exhibition, transl. Ágnes Latorre. Budapest: Országos Széchényi Könyvtár, 2018. . “F 8 (= Kalauz / Guide 2018, Kat. F8) Eusebius Krónikájának második könyve (Chronikoi kanones) Szent Jeromos latin fordításában" [The second book of Eusebius' Chronicle in Saint Jerome’s translation]. In "Az ország díszére." A Corvina könyvtár budai mühelye: Kiállitási katalógus [The Corvina Library and the Buda workshop: Exhibition catalogue], edited by Edina Zsupán, 309-311. Budapest: Országos Széchényi Könyvtár, 2020. 


\section{ABSTRACT}

Saint Jerome was a prominent figure in the Hungarian-language literature prepared mainly for nuns in the last decade of the fifteenth and the first decades of the sixteenth century. A Dominican codex contains two legends about him (one of them is the translation of Pseudo-Augustine's Epistola ad Cyrillum de magnificentiis beati Hieronymi), while a Franciscan manuscript preserved the Hungarian version of the Regula monachorum attributed to Jerome. The Franciscan András Nyújtódi represented the Church Father as a model teacher and translator when quoting the great biblical philologist's dedicatory lines to the Book of Judith in his translation of the same biblical book, which this Transylvanian friar prepared as a private reading for his sister, a Franciscan tertiary. Another self-proclaimed follower of Jerome's translating activity was an anonymous Carthusian monk, who mentioned the Slavic Bible and liturgy prepared by the saintly scholar. - The paper presents the texts by and about Jerome, which can be found in the not very extensive late medieval Hungarian-language literature, and traces the image of the saintly author as represented for the audience of the corpus produced for Observant Dominican and Franciscan nuns, tertiaries, and in a few cases perhaps laypersons.

KEYWORDS: medieval Hungarian-language literature, Saint Jerome, Pseudo-Jerome, reception of Jerome, Bible translation, Vita et transitus Sancti Hieronymi 


\section{SVETI HIERONIM KOT ZGLED IN AVTOR ZA REDOVNICE} V ZGODNJIH MADŽARSKIH BESEDILIH

\section{IZVLEČEK}

Lik svetega Hieronima je imel pomembno mesto v madžarski književnosti, namenjeni predvsem redovnicam, v zadnjem desetletju petnajstega in prvih desetletjih šestnajstega stoletja. Eden od dominikanskih kodeksov vsebuje dve legendi o njem (ena od njih je prevod psevdo-Avguštinove Epistola ad Cyrillum de magnificentiis beati Hieronymi), eden od frančiškanskih rokopisov pa je ohranil madžarsko različico Hieronimu pripisanega besedila Regula monachorum. Frančiškan András Nyújtódi je cerkvenega očeta predstavil kot vzornega učitelja in prevajalca, ko je odlomek iz posvetila velikega svetopisemskega filologa v Juditini knjigi citiral v svojem prevodu iste svetopisemske knjige, ki jo je ta transilvanski menih pripravil kot zasebno berilo za svojo sestro, frančiškansko tretjerednico. Drugi samooklicani Hieronimov prevajalski dedič je bil anonimni kartuzijanski menih, ki je omenil slovansko Sveto pismo in liturgijo, ki jo je pripravil svetniški učenjak. $\mathrm{V}$ prispevku so predstavljena Hieronimova besedila in besedila o njem, ki jih lahko najdemo $\mathrm{v}$ razmeroma redkih poznosrednjeveških zapisih v madžarščini, skupaj s svetnikovo podobo, kot je bila posredovana bralcem knjig, spisanih za dominikanke in frančiškanke, za tretjerednice - in v nekaj primerih morda za laikinje.

KLJUČNE BESEDE: srednjeveška književnost v madžarskem jeziku, sveti Hieronim, psevdo-Hieronim, Hieronimova recepcija, prevod Svetega pisma, Vita et transitus Sancti Hieronymi 